\title{
Swimming performance of epigeal and hypogeal species of Characidae, with an emphasis on the troglobiotic Stygichthys typhlops Brittan \& Böhlke, 1965
}

\author{
Francisco Alexandre Costa Sampaio ${ }^{1}$, Paulo Santos Pompeu ${ }^{1}$, \\ Hersília de Andrade e Santos ${ }^{2}$, and Rodrigo Lopes Ferreira ${ }^{1}$
}

\begin{abstract}
:
Costa Sampaio F.A., Santos Pompeu P., de Andrade e Santos H. and Lopes Ferreira R. 2012 . Swimming performance of epigeal and hypogeal species of Characidae, with an emphasis on the troglobiotic Stygichthys typhlops Brittan \& Böhlke, 1965. International Journal of Speleology, 41(1), 9-16. Tampa, Florida (USA). ISSN 0392-6672. http://dx.doi.org/10.5038/1827-806X.41.1.2

Swimming performance of fish constitutes a good ecophysiological tool to evaluate the ability of species to use different types of habitats. In order to understand how the swimming performance is related to the hydraulic environment, we compared the critical velocity of five fish (Characidae): Stygichthys typhlops (groundwater troglobiotic); Piabina argentea and Bryconamericus stramineus (riverine); Hemigrammus marginatus (generalist, found in rivers and floodplains) and Psellogrammus kennedyi (lacustrine). Swimming speed tests were performed in a respirometer-type apparatus. Total body length was the variable that best explained the maximum speed attained by all species under study. The critical swimming speed values (in body lengths per second) for each species were as follows: P. argentea (13.75); B. stramineus (9.32); H. marginatus (6.32); P. kennedyi (4.00); and lower in hypogean species, S. typhlops (3.31). All data of this study suggest a strong correlation between swimming performance and the hydraulic environment in which the species are found. The riverine, generalist and lacustrine species (the troglobiotic being included in the last group) showed a trend toward a decrease in speed.
\end{abstract}

Keywords: characins; troglobiotic; critical swimming speed; fish performance; São Francisco basin; Brazil

Received 3 January 2011; Revised 17 February 2011; Accepted 15 March 2011

\section{INTRODUCTION}

Swimming performance studies are relevant in evaluating the influence that different environmental conditions have on fish, as well as the survival of fish in a given ecological system (Plaut, 2001). Such studies can also increase the understanding of ecological factors related to the establishment of a certain species in an environment with specific hydraulic characteristics.

The subterranean fish (troglomorphic and nontroglomorphic) present a wide distribution throughout the world, occurring in several types of environments such as the phreatic and karstic aquifers (including the epicarst), hyporheic habitats and base level courses (Bichuette \& Trajano, 2010), and most of the

${ }^{1}$ Federal University of Lavras, Department of Biology, Postgraduate Program in Applied Ecology - Caixa Postal 3037 -37200-000, Lavras, MG, Brasil. (alexandre.sampaio@ rocketmail.com)

${ }^{2}$ Minas Gerais State Federal Center for Technological Education, Department of Civil Engineering, Campus II - Av. Amazonas, 7675, Nova Gameleira, 30510-000, Belo Horizonte, MG, Brasil knowledge of those species arises from caves (Weber et al, 1996). About 150 described hipogean species are distributed in those environments (Proudlove, 2010), and in Brazil that ichthyofauna represents an expressive diversity, with about 25 species (Trajano \& Bichuette, 2010).

Although some studies conducted with species hipogean have not specifically focused on the swimming performance, some studies in that line have been contributing to the understanding of that important activity in fish, for example the natatory behavior of amblyopsids (Poulson \& White, 1969) and the swimming of Astyanax fasciatus as an orientation element in its surroundings (Holbrook et al., 2007; Windsor et al., 2008, 2010a,b). In comparative studies of hypogean and epigean species, in general, many cave fish studied presented natatory behaviors completely different from their epigean relatives, where they are oriented mainly by vision (Parzefall, 1996).

The swimming performance of fish can fall into one of three general categories: sustained swimming, prolonged swimming, or burst swimming. Sustained swimming occurs at relatively slow speeds and utilizes 
primarily red muscle fibers that are fueled by energy derived from the aerobic metabolism (Beamish, 1978). This allows fish to maintain sustained swimming velocities for long periods (at least $200 \mathrm{~min}$ ) without fatiguing (Beamish, 1978). Burst swimming involves white muscle fibers that utilize energy derived from anaerobic processes to attain relatively high speeds for less than 15-20 s (Beamish, 1978). Prolonged swimming covers a spectrum of velocities between sustained and burst swimming, using red (aerobic) and white (anaerobic) muscle fibers in concert.

Prolonged swimming speed is the type of swimming speed that is most commonly measured in laboratory. The main subcategory of prolonged swimming speed is critical swimming speed, which was first defined and employed by Brett (1964). Critical swimming speed corresponds to the maximum speed $\left(V_{\max }\right)$ a fish is able to maintain in a flow whose speed is increased $(\Delta V)$ at predetermined time intervals $(\Delta t)$. Since it was first proposed, critical swimming speed has been the subject of numerous studies (Hammer, 1995), which have allowed detailed comparisons to be drawn among many species in terms of their swimming performance.

The freshwater ichthyofauna of the Neotropical region is the most diverse in the world (LoweMcConnell, 1999). However, studies of swimming performance are available for few migratory species, with the objective of creating a basis for the use of fish passage systems (Santos, 2007; Santos et al., 2007; 2008) and to understand the perception of objects in the flow fields using the lateral line system (Holbrook et al., 2007; Windsor et al., 2008, 2010a,b).

Among South American fish, those of the order Characiformes are noteworthy and the order includes herbivorous, detritivorous, and carnivorous species, and some of these are highly specialized (Britski et al., 1999; Lowe-McConnell, 1999).

In Characidae there is considerable diversification among the group in relation to the different environments with which they are associated, including the riverine species, lacustrine species and subterranean species (which inhabit phreatic zones).

Stygichthys typhlops is one of only two troglobiotic species in the Characidae (Figure 1E). This species

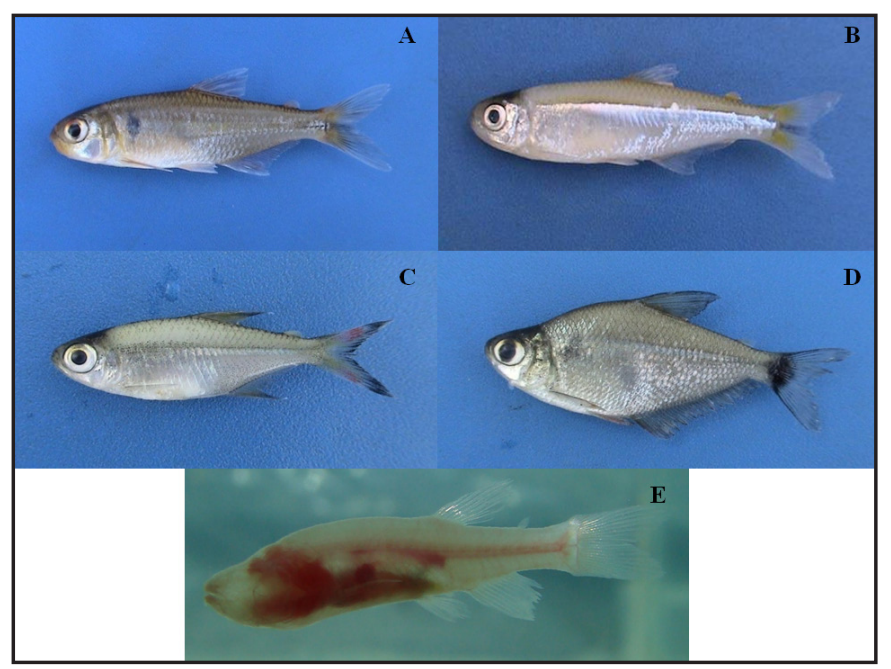

Fig. 1. Fish species tested in this study. has strong regressive characteristics such as the loss of circumorbital bones, which suggests a much more advanced stage of specialization for the subterranean environment than that observed in the other species, such as the Mexican blind cavefish, Astyanax fasciatus, which displays only partial fragmentation of these bones (Romero \& Paulson, 2001). This characteristic is strongly associated with the loss of eyes among cave-dwelling fish (Romero \& McLeran, 2000). Due to its high degree of specialization, limited geographic distribution, and habitat modification, as well as to being only the second troglobiotic characid, it is notable among subterranean ichthyofauna (Moreira et al., 2010). Most of the information regarding the species, including population aspects, habitat characteristics, reproduction and feeding remain unknown. Although information regarding S. typhlops habitat is scarce (Romero \& McLeran, 2000), Moreira et al. (2010) have suggested that the occurrence of the species is associated with a single subterranean drainage basin (small river), and the species is critically endangered due to its high endemism.

The aim of the present study was to provide information on the swimming performance of Stygichthys typhlops and to compare with different species of Neotropical fish (Characidae) in terms of their speed and determine whether the hydraulic environment was able to influence the swimming performance of the species tested. Because morphological variations can affect swimming performance (Breda et al., 2005) and habitat use (Fulton et al., 2005), we chose to study five species that presented the same ecomorphological pattern.

\section{Species studied}

We tested the swimming performance of four epigeal species (Piabina argentea (Figure 1A), Bryconamericus stramineus (Figure 1B), Hemigrammus marginatus (Figure 1C) and Psellogrammus kennedyi (Figure 1D)) and one hypogeal species (Stygichthys typhlops) (Figure 1E), all of which belong to the order Characiformes. These species occur in riverine, lacustrine and phreatic zones and are included in the incertae sedis group of the Characidae.

Averaging approximately $7 \mathrm{~cm}$ in length, $P$. argentea, and $B$. stramineus, are widely distributed in the São Francisco River and Paraná River basins (Lima et al., 2003). Both are lotic species that preferably inhabit rivers and streams (Casatti \& Castro, 1998; Alves \& Pompeu, 2001).

$H$. marginatus, which grows to maximum length of $4.5 \mathrm{~cm}$, is widely distributed in South America, occurring in the São Francisco River, Paraná River, Paraguay River, Orinoco River, Guaporé River, and Amazon River basins (Lima et al., 2003). It is a generalist, lentic species that inhabits small rivers and floodplains (Alves \& Pompeu, 2001; Langeani et al., 2007).

Distributed throughout the São Francisco River and Paraguay River basins, the lentic species $P$. kennedyi can grow to $5.9 \mathrm{~cm}$ in length (Lima et al., 2003) and is found in floodplains (Alves \& Pompeu, 2001). 
Locally known as piaba-branca or piaba-cega ("white cavefish" or "blind cavefish"), S. typhlops is a troglobiotic species that occurs in phreatic zones in the Jaíba region of northern Minas Gerais, a state in southeastern Brazil. The distribution of S. typhlops is limited to that area, at the drainage basin of Escuro Creek, a tributary of the Verde Grande River, in the upper São Francisco River region. The species was accidentally discovered in 1962, during groundwater pumping, being subsequently rediscovered by Moreira et al. (2010).

\section{Sampling}

The fish were collected from the São Francisco River and Grande River basins, in the state of Minas Gerais between september and october 2008, except for S. typhlops (june 2008). P. argentea individuals were collected from the Curimatai River (17\%59'33.3”S, 44¹0'48.2'W), in São Francisco basin and sampling was carried out with the aid of hand trawl nets and seines. B. stramineus individuals were captured in the Grande River (2108'39.0"S, 4502'14.2'W), by means of hand trawl nets and seines. $H$. marginatus and $P$. kennedyi individuals were collected from the Olaria lake in the floodplains of the das Velhas

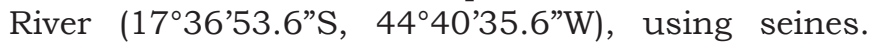
S. typhlops individuals were collected from a well on the Lajeado Farm (15²4'41,7"S; 4345'19,7”W), located in north of the state of Minas Gerais, in São Francisco basin. The well is located at the bottom of a sinkhole, approximately $3 \mathrm{~m}$ below ground level, where groundwater emerges from among the rocks. For many years, the local residents used the well for irrigation. The well is currently deactivated. S. typhlops individuals were captured using hand nets.

The fish were transported in aerated plastic containers at controlled temperatures. In the laboratory, the fish were acclimatized and transferred to fish tanks, and the temperatures were similar to those at the collection sites $\left(19-20^{\circ} \mathrm{C}\right)$.

To avoid any loss of swimming performance, the fish were maintained in the laboratory for no more than 7 days before testing.

\section{Experimental procedure}

An experimental apparatus, based on the Brett respirometer, was constructed in order to test the swimming performance of the fish (Figure 2). The apparatus consisted of a flume, in which the fish were swim against the current generated by a centrifugal pump (Figure 2A).

The main tube was composed of three sections. Two of the sections were made of PVC and one of the sections (the central part of the tube), where the fish were confined, was made of acrylic (Figure 2B), which allowed the swimming visualization. The fish were introduced via a T-junction with an upward positioned intake (Figure 2C) and removed via a T-junction with a downward positioned outtake. The fish were confined in the central part of the tube by two screens (Figure 2D). The polyvinyl chloride tubes were connected to the two ends of the acrylic tube in order to reduce the interference of the pumps and the drain.

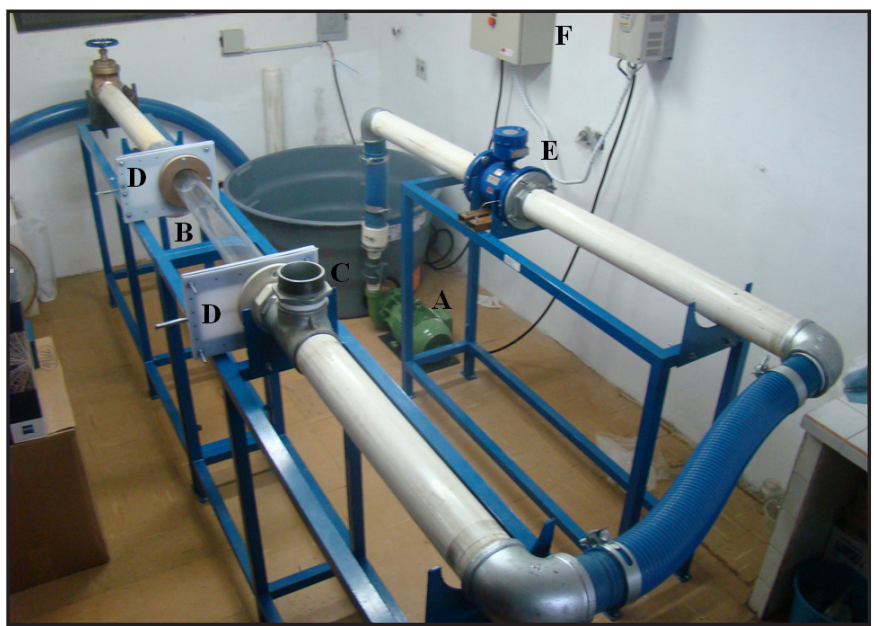

Fig. 2. General view of the apparatus and it's components.

To determine water discharge, the apparatus was equipped with an electromagnetic flowmeter (Figure $2 \mathrm{E})$ and the flow was changed by frequency converter (Figure $2 \mathrm{~F}$ ), which allow to increase the mean velocity in small steps of values $(1 \mathrm{~cm} / \mathrm{s})$.

The critical swimming speed tests, or increasing velocity tests, were performed based on the experimental procedure described by Brett (1964). We tested 20-27 individuals of the epigeal species and 12 individuals of the hypogeal species in order to ensure that a wide range of sizes were being tested (Figure 3). Fewer $S$. typhlops individuals were tested due to the smaller size of this population.

After the fish had adapted to the temperature of the water in the apparatus and had been introduced into the test section, the test began, with the pumps at low rotation speed $(5 \mathrm{~cm} / \mathrm{s})$. After the first $5 \mathrm{~min}$, the mean velocity was increased, in $5 \mathrm{~cm} / \mathrm{s}$ increments $(\Delta V)$, at 5 -min intervals $(\Delta t)$. These incremental values were based on the speed control options offered by the apparatus and the total time of the test. We measured how long the fish were able to swim at that speed $\left(V_{\max }\right)$ before suffering fatigue. This was considered the moment when the fish were no longer able to stay in the test section, after several bursts of swimming activity.

The values of critical swimming speed were calculated with the following formula (equation 1):

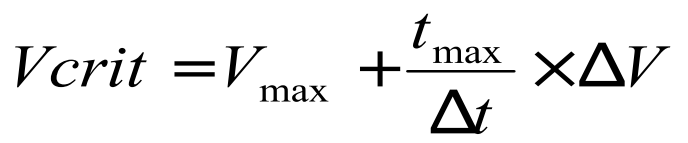

where $V_{\max }$ is the maximum speed $(\mathrm{m} / \mathrm{s}), \Delta V$ is the increase in speed $(\mathrm{m} / \mathrm{s}), \Delta t$ is the time interval $(\mathrm{s})$, and $t_{\max }$ is the swimming time during the last time interval (s).

\section{Data analysis}

During each test, water quality parameters such as dissolved oxygen, $\mathrm{pH}$ and temperature were monitored. After the tests, the fish were weighed and measured: total length -TL (distance from snout to end of caudal peduncle); standard length - SL (distance from snout to end of caudal fin); maximum height and maximum width. Weights and lengths are expressed in grams and centimeters, respectively. 

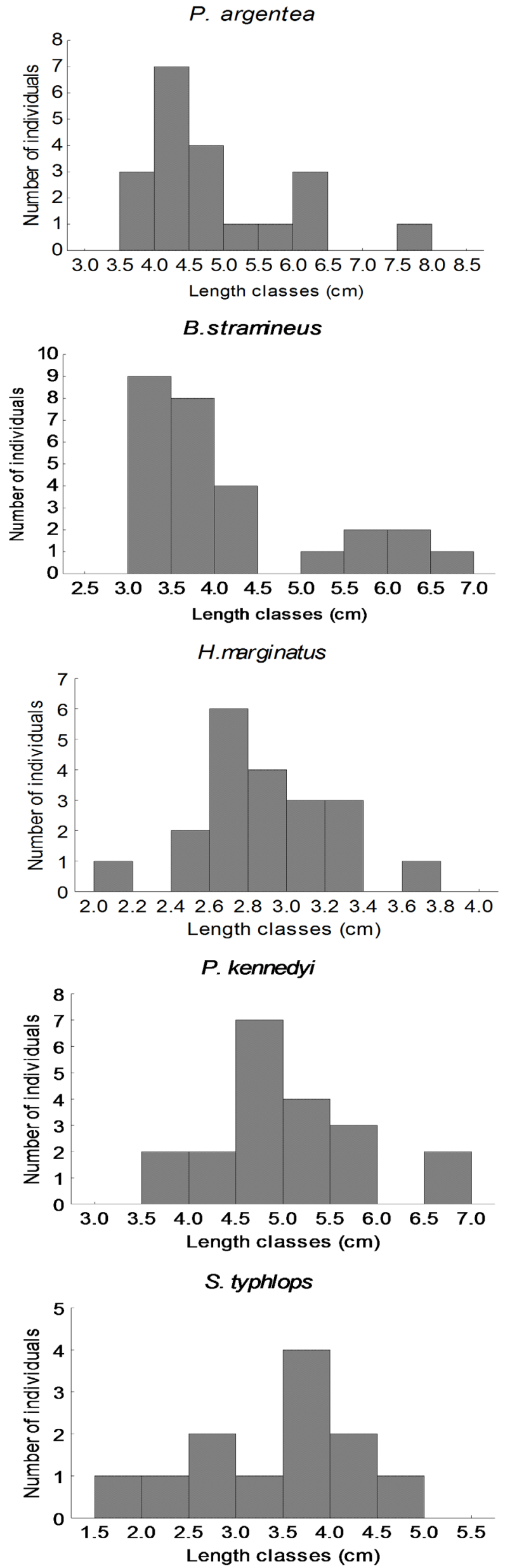

Fig. 3. Number of fish tested to determine critical swimming speed, by length class.
The solid blocking effect occurs due to the obstruction of the flow by the body. In this case the fish block the water flow in the test section and, according Webb (1975) equations (2) can be applied for swimming studies inside hydrodynamics apparatus:

$$
V_{\text {corrected }}=\frac{V_{\text {measured }} K_{3} \mathrm{~T}_{1}(\text { fish volume })}{C^{3 / 2}}
$$

Where $V_{\text {measured }}$ is the critical measured speed $(\mathrm{m} / \mathrm{s})$, $K_{3}$ is a dimensionless factor of the body shape (Pope $\&$ Hae, 1966), $\tau_{1}$ is dimensionless factor of the test section layout (for circular sections $\tau_{1}=0.8 \mathrm{~cm}$ (Pope $\&$ Hae, 1966)), $C$ is the cross-sectional area of the tunnel $\left(\mathrm{cm}^{2}\right)$ and $\mathrm{Vol}$ is the fish volume $\left(\mathrm{cm}^{3}\right)$. According to Pope \& Hae (1966), a good approximation for volume of a circular revolution solid $\left(\mathrm{cm}^{3}\right)$ is equation (3):

$$
\text { Volume }=0,45 e^{2} L
$$

In this study, $e(\mathrm{~cm})$ is the maximum width of the fish (the mean between the maximum width and weight) and $L(\mathrm{~cm})$ is the total length of the fish.

The relationship between critical swimming speed and fish length (total and standard length) and the relationship between critical swimming speed and fish weight were tested by linear regression. Relative velocities in length per second were compared among species using ANOVA. Variables with non-normal distribution were transformed into their natural logarithms. All analyses were performed using the Statistica software (Statsoft, 2009).

\section{RESULTS}

In all tests performed, the quality of the water in the experimental apparatus was satisfactorily maintained, with dissolved oxygen concentrations higher than 5 $\mathrm{mg} / \mathrm{L}$ and $\mathrm{pH}$ ranging from 6 to 7 . The temperatures $\left({ }^{\circ} \mathrm{C}\right)$ during the tests were: $P$. argentea (20.3 \pm 1.07$) ; B$.

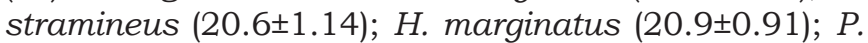

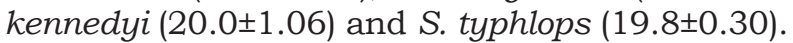

We analyzed the behavior of the fish as they attempted to avoid contact with the confining screen downstream. This behavior consisted of short, rapid bursts of swimming, with strong forward propulsion, similar to the behavior observed during burst swimming, which is commonly evaluated under laboratory conditions (Beamish, 1978). This movement was observed in all species, in individuals belonging to different length classes. This type of swimming occurred at a speed that was close to the maximum speed limit that each species was able to attain: $P$. argentea (mean 0.66 $\mathrm{m} / \mathrm{s}) ;$ B. stramineus $(0.37 \mathrm{~m} / \mathrm{s}) ;$ P. kennedyi $(0.20 \mathrm{~m} / \mathrm{s})$; $H$. marginatus $(0.18 \mathrm{~m} / \mathrm{s})$ and $S$. typhlops $(0.11 \mathrm{~m} / \mathrm{s})$.

Significant correlations were observed between critical swimming speed and the size of the fish tested, as well as between critical swimming speed and the weight. Total length was the variable that best explained critical swimming speed, and this correlation was significant for all species evaluated (Figure 4, Table 1). Standard length and weight were also significantly related to critical swimming speed in all but two species ( $H$. marginatus and $P$. argentea), in which only standard lentgth was significantly related to critical swimming speed. 
Table 1. Relationship between the critical swimming speed (CSS) of the species tested and the variables "total length" (TL), "standard length" (SL) and "weight" (W), as well as the equations between TL.

\begin{tabular}{|c|c|c|c|c|c|c|c|}
\hline \multirow{2}{*}{ Species } & \multicolumn{3}{|r|}{$\mathrm{TL}$} & \multicolumn{2}{|c|}{ SL } & \multicolumn{2}{|c|}{ Weight } \\
\hline & $r^{2}$ & $\mathrm{p}$ & Equations & $r^{2}$ & $\mathrm{p}$ & $r^{2}$ & $\mathrm{p}$ \\
\hline Piabina argentea & 0.37 & $\begin{array}{c}< \\
0.01\end{array}$ & $\mathrm{CSS}=3.02+0.73 \log \mathrm{TL}$ & 0.38 & $\begin{array}{c}< \\
0.01\end{array}$ & 0.22 & 0.03 \\
\hline $\begin{array}{l}\text { Bryconamericus } \\
\text { stramineus }\end{array}$ & 0.60 & $\begin{array}{c}< \\
0.01\end{array}$ & $\mathrm{CSS}=1.16+1.7 \log \mathrm{TL}$ & 0.60 & $\begin{array}{c}< \\
0.01\end{array}$ & 0.59 & $<0.01$ \\
\hline $\begin{array}{l}\text { Hemigrammus } \\
\text { marginatus }\end{array}$ & 0.22 & $\begin{array}{c}< \\
0.05\end{array}$ & $\mathrm{CSS}=1.54+1.2 \log \mathrm{TL}$ & 0.12 & 0.12 & 0.22 & 0.03 \\
\hline $\begin{array}{l}\text { Psellogrammus } \\
\text { kennedyi }\end{array}$ & 0.68 & $\begin{array}{c}< \\
0.01\end{array}$ & $\mathrm{CSS}=0.4+1.59 \log \mathrm{TL}$ & 0.68 & $\begin{array}{c}< \\
0.01\end{array}$ & 0.67 & $<0.01$ \\
\hline $\begin{array}{l}\text { Stygichthys } \\
\text { typhlops }\end{array}$ & 0.72 & $\begin{array}{c}< \\
0.01\end{array}$ & $\mathrm{CSS}=1.15+1.03 \log \mathrm{TL}$ & 0.73 & $\begin{array}{c}< \\
0.01\end{array}$ & 0.46 & $<0.01$ \\
\hline
\end{tabular}
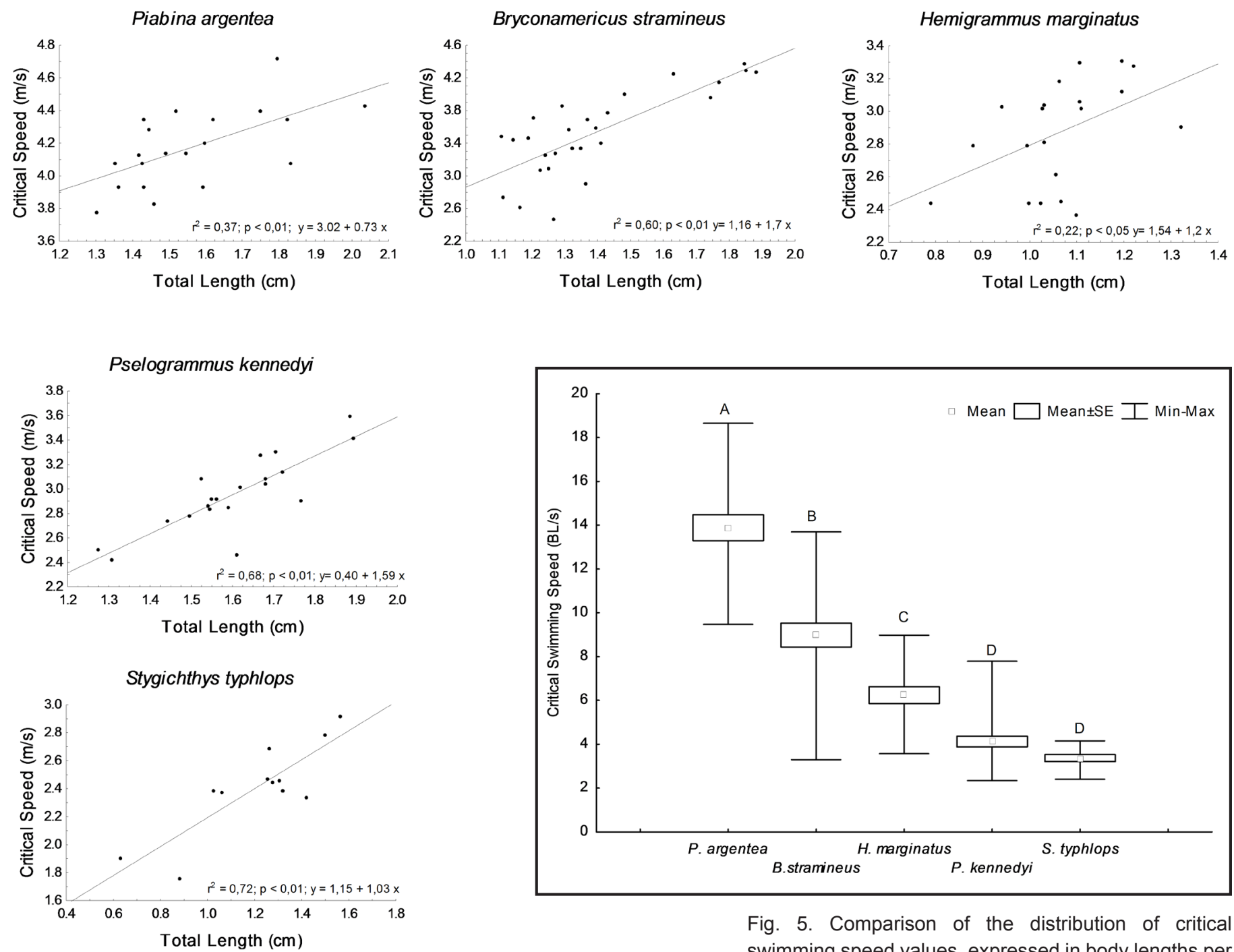

Fig. 4. Relationship between the critical swimming speed $(\mathrm{cm} / \mathrm{s})$ $(\mathrm{log})$ and total length $(\mathrm{cm})(\mathrm{log})$ of the species analyzed.

Fig. 5. Comparison of the distribution of critical swimming speed values, expressed in body lengths per second $(B L / s)$, for each of the species tested. Different letters indicate significant differences in speed. 
When the relative velocity, expressed in body lengths per second (BL/s), were compared, $P$. argentea showed the highest value $(13.75 \mathrm{BL} / \mathrm{s})$, followed by $B$. stramineus $(9.32 \mathrm{BL} / \mathrm{s}), H$. marginatus $(6.32 \mathrm{BL} / \mathrm{s})$, P. kennedyi $(4.00 \mathrm{BL} / \mathrm{s})$, and $S$. typhlops $(3.31 \mathrm{BL} / \mathrm{s})$. Significant differences were observed for all species except the last two. S. typhlops also showed the least variation in swimming performance among the species tested (Figure 5).

\section{DISCUSSION}

Historically, studies of the swimming performance of fish have principally focused on species from temperate climates (Jones et al., 1974; Beamish, 1978, 1981; Kolok, 1992; Hammer, 1995; Plaut, 2001; Mateus et al., 2008), and in the Neotropical region have focused mostly on migratory fish species (Santos et al., 2007; 2008). Studies on the swimming behavior of subterranean species were performed only for Astyanax fasciatus, and have focused on hydrodynamic imaging (Holbrook et al., 2007; Windsor et al., 2008, 2010a,b). Comparative studies on swimming performance of epigeal and hypogeal fish species had never been conducted.

Recent studies about fish swimming show differences between the fish speeds measured in flumes and the fish speeds observed in field (Peake, 2004). The reasons may be due to the fact that confined fish will not swim to complete physiological exhaustion or to differences in the energetic costs, associated with confined and unconfined swimming (Peake, 2004) and related to the use of different gaits during the tests that marks the switch from aerobic to anaerobic power output (Svendsen et al., 2010). Critical swimming speed has little biological significance, because the gradual increases in water velocity applied in laboratory tests are not encountered in nature. However, this experimental methodology has been considered a powerful tool to compare species in terms of their swimming performance (Hammer, 1995), because the experiment is easy to standardize and perform in a laboratory.

The strong propulsion type of swimming behavior (without the use of different gait) - which was observed for all size ranges - generally occurred during the second half of the test period. According to Beamish (1978), fish can swim at this speed only for short periods of time $(<20 \mathrm{~s})$. This burst of speed is essential for the survival of many species, being used as a facilitator for the capture of prey, escape from predators, or negotiation of rapid-flow sections of rivers (Beamish, 1978).

The strong correlation between critical swimming speed and total length reflects the importance of the caudal fin, one of the propulsion elements in fish that present locomotion patterns of the subcarangiform type (Webb, 1975), which is the case of the species evaluated in the present study. The great influence of this variable on the swimming performance of fish had previously been observed in two other Neotropical species already studied - Pimelodus maculatus and Leporinus reinhardti (Santos et al., 2007; 2008) - both of which present the same locomotion pattern. Body length is one of the most important characteristics that influence the swimming performance of fish (Beamish, 1978; Hammer, 1995; Plaut, 2001) and has been positively correlated with water velocity (Watson \& Balon, 1984; Wikramanayake, 1990).

In the present study, the relative speed $(\mathrm{BL} / \mathrm{s})$ developed by the different species was clearly dependent on the conditions of the flow as observed by Fulton et al. (2005). The speed attained by the species that are typically found in lotic environments - $P$. argentea and $B$. stramineus - constituted the highest critical swimming speed values (in $\mathrm{BL} / \mathrm{s}$ ) ever obtained in laboratory experiments involving freshwater species (Figure 5). These values were higher than those found by Santos et al. $(2007,2008)$ for the Neotropical migratory species $P$. maculatus and L. reinhardti, which attained speeds of approximately 6 and $8 \mathrm{BL} / \mathrm{s}$, respectively. This might be due to the fact that these species often occupy environments in which the speed of the current varies.

Although the $H$. marginatus and $P$. kennedyi individuals analyzed in the present study were captured in the same lake, $H$. marginatus individuals (which can also be found in lotic systems) swam at intermediate speed (Figure 5), which was nevertheless higher than that of $P$. kennedyi individuals (the occurrence of which is limited to floodplains) (Alves \& Pompeu, 2001).

Body shape can explain the low speeds attained by $P$. kennedyi individuals, whose bodies are laterally compressed and taller than those of the remaining individuals tested in the present study, which had lower, fusiform bodies (Wikramanayake, 1990). Since $P$. kennedyi individuals occur in lakes with abundant submerged vegetation, this morphology can be related to maneuverability in situations of capture of prey and escape from predators (Breda et al., 2005). Undulatory swimmers use the mid-dorsal and mid-ventral fins more than their other fins. These organisms are specialized for precise maneuvers such as those executed amid tangled aquatic vegetation (Breda et al., 2005; Hildebrand \& Goslow, 2006), since tall, laterally compressed, bodies are inversely correlated with high speed (Wikramanayake, 1990). The speed values for this species were close to those observed for $S$. typhlops, suggesting that the lake and the subterranean environment inhabited by the species presented similar hydraulic conditions (Figure 5). During the process of specialization of the species for the conditions of the subterranean environment (as evidenced by aspects such as the lack of eyes and pigmentation), there are indications of a swimming specialization for the velocity of groundwater.

Previous studies have indicated that faster swimming blind cave fish would enhance their ability to detect their surroundings (Teyke, 1989). However, studies on hydrodynamic imaging by blind Mexican cave fish (Astyanax fasciatus) have indicated that, in still water with no environmental noise, the relative change in the stimulus to the lateral line is only weakly affected by swimming speed, and at higher swimming speeds the predicted detected distance actually decreases (Windsor et al, 2008a, 2008b).

Of the species studied, $S$. typhlops presented the smallest swimming performance, the smallest intraspecific differences in swimming performance 
in $\mathrm{BL} / \mathrm{s}$, and the explanatory power of body size (for the speed attained) was therefore high. This might be due to the greater stability of the environment in which the species lives, where groundwater velocity is probably low and relatively constant. The low speed and small variation observed among individuals might correspond to the specialization of the species for the subterranean environment. This reflects a possible advantage of mean swimming speed over extreme swimming speed, because extreme swimming is energetically costly and might be disadvantageous. A reduction in extremely high swimming speeds for an environment with low discharge can represent a major economy of energy for the individuals. Since food resources are generally scarce in the subterranean environment, a reduction in metabolic rates can represent a positively selected condition in these environments (Culver, 1982). A reduction in metabolism can directly reflect on mobility and, consequently, on a reduction in high speeds. The low swimming performance of $S$. typhlops might be evidence of the hydrodynamics in the phreatic zone, a habitat about which there is little information. The occurrence of S. typhlops in this environment suggests that measures should be adopted to ensure appropriate management of soil and groundwater use, thereby ensuring the conservation of the species.

The determination of the swimming performance of fish constitutes a good ecophysiological tool to evaluate the ability of species to use different types of habitats according to their speed (Plaut, 2001), indicating a division of the use of space. In addition, studies conducted in this area reinforce the role of hydraulic influence in the appearance of certain species that tolerate high discharge (Langerhans et al., 2003). In the present study, the comparison of different species from the same family, with the same swimming pattern (subcarangiform), and existing in different hydraulic environments showed that swimming performance can vary widely among species, probably in response to different environmental conditions as suggested by Fulton et al. (2005).

\section{ACKNOWLEDGEMENTS}

We are extremely grateful for the financial support provided by FAPEMIG - Fundação de Amparo à Pesquisa do Estado de Minas Gerais (grant no. CRAAPQ-3490.5.03/07). We would also like to thank CAPES - Coordenação de Aperfeiçoamento de Pessoal de Nivel Superior (for the grants awarded to F.A.C.S.) and IBAMA - Instituto Brasileiro do Meio Ambiente e dos Recursos Naturais Renováveis (license no. 132952). We are also grateful to Carlos B. M. Alves and Fábio Vieira for the financial support provided for the construction of the apparatus, to Miriam A. Castro for her invaluable aid in performing the tests, and to the reviewers for their contribution.

\section{REFERENCES}

Alves C.B.M. \& Pompeu P.S., 2001 - Peixes do Rio das Velhas: passado e presente. SEGRAC, Belo Horizonte, $194 \mathrm{p}$.

Beamish F.W.H., 1978 - Swimming capacity. In: Hoar W.S. \& Randall D.J. (Eds.), Fish physiology. New York, Academic Press: 101-187.
Beamish F.W.H., 1981 - Swimming performance and metabolic rate of three tropical fishes in relation to temperature. Hydrobiologia, 83: 245-254. http://dx.doi.org/10.1007/BF00008273

Bichuette M. E. \& Trajano E. 2010 - Conservation of subterranean fishes In: Trajano E., Bichuette M. E. \& Kapoor B. G. (Eds.), Biology of subterranean fishes. Science Publishers, Enfield. 65-80.

Breda L., Oliveira E.F. \& Goulart E., 2005 - Ecomorfologia de locomoção de peixes com enfoque para espécies neotropicais. Acta Scientiarum Biological Sciences, 27: 371-381. http://dx.doi.org/10.4025/actascibiolsci.v27i4.1271

Brett J.R., 1964 - The respiratory metabolism and swimming performance of young sockeye salmon. Journal of the Fisheries Research Board of Canada, 21: 1183-1226. http://dx.doi.org/10.1139/f64-103

Britski H.A., Silimon K.Z.S. \& Lopes B.S., 1999 Peixes do Pantanal: manual de identificação. Embrapa, Brasilia, $184 \mathrm{p}$.

Casatti L. \& Castro R.M.C., 1998 - A fish community of the São Francisco River headwaters riffles, southeastern Brazil. Ichthyological Exploration of Freshwaters, 9: 229-242.

Culver D.C., 1982 - Cave life: evolution and ecology. Harvard University Press, Cambridge, 189 p.

Fulton C.J., Bellwood D.R. \& Wainwright P.C., 2005 - Wave and swimming performance shape coral reef fish assemblages. Proceedings of the Royal Society B, 272: 827-832. http://dx.doi.org/10.1098/rspb.2004.3029

Hammer C., 1995 - Fatigue and exercise tests with fish. Comparative Biochemistry and Physiology: part A, 112: 1-20.

Hildebrand M. \& Goslow G.E., 2006 - Análise da estrutura dos vertebrados. Atheneu, São Paulo, 642 p.

Jones D.R., Kiceniuk J.W. \& Bamford O.S., 1974 Evaluation of the swimming performance of several fish species from the Mackenzie River. Journal of the Fisheries Research Board of Canada, 31: 16411647. http://dx.doi.org/10.1139/f74-206

Kolok A.S., 1992 - The swimming performance of individual largemouth bass (Micropterus salmoides) are repeatable. The Journal of Experimental Biology, 170: 265-270.

Langeani F., Castro R.M.C., Oyakawa O.T., Shibatta O.A., Pavanelli C.S. \& Casatti L., 2007 Ichthyofauna diversity of the upper rio Paraná: present composition and future perspectives. Biota Neotropica, 7: 181- 197. http://dx.doi.org/10.1590/S1676-06032007000300020

Langerhans R.B., Layman C.A., Langerhans A. \& Dewitt T.J., 2003 - Habitat-associated morphological divergence in two Neotropical fish species. Biological Journal of the Linnean Society, 80: 689-698. http://dx.doi.org/10.1111/j.1095-8312.2003.00266.x Lima F.C.T., Malabarba L.R., Buckup P.A., Silva J.F.P., Vari R.P., Harold A., Benine R., Oyakawa O.T., Pavanelli C.S., Menezes N.A., Lucena C.A.S., Malabarba M.C.S. L., Lucena Z.M.S., Reis R.E., Langeani F., Cassati L., Bertaco V.A., Moreira C. \& Lucinda P.H.F., 2003 - Genera Incertae Sedis in Characidae. In: Reis R.E., Kullander S.O. \& Ferrraris Júnior C.J. (Eds.), Check list of the freshwater fishes of South and Central America. EDIPUCRS, Porto Alegre: 106-169. 
Lowe-McConnell R.H., 1999 - Estudos ecológicos de comunidades de peixes tropicais. Universidade de São Paulo, São Paulo, 536 p.

Mateus C.S., Quintella B.R. \& Almeida P.R., 2008 - The critical swimming speed of Iberian barbel Barbus bocagei in relation to size and sex. Journal of Fish Biology, 73: 1783-1789. http://dx.doi.org/10.1111/j.1095-8649.2008.02023.x

Moreira C.R., Bichuette M.E., Oyakawa O.T., De Pinna M.C.C. \& Trajano E., 2010 - Rediscovery and redescription of the unusual subterranean characiform Stygichthys typhlops, with notes on its life history. Journal of Fish Biology, 76: 1815-1824. http://dx.doi.org/10.1111/j.1095-8649.2010.02625.x

Parzefall, J. 1996 - Behavioural adaptations of cave fishes. In: Weber A., Proudlove G., Parzefall J., Wilkens H., \& Nalbant T. (Eds.), Pisces (Teleostei). L'Encyclopaedia Biospeologica Tome II; Laboratoire Souterrain \& L'Institut de Speologie Emile Racovitza, 1191-1200.

Peake S., 2004 - An evaluation of the use of critical swimming speed for determination of culvert water velocity criteria for smallmouth bass. Transactions of the American Fisheries Society, 133: 1472-1479. http://dx.doi.org/10.1577/T03-202.1

Plaut I., 2001 - Critical swimming speed: its ecological relevance. Comparative Biochemistry and Physiology: part A, 131: 41-50.

Pope A. \& Rae W.H., 1966 - Low-speed wind tunnel testing. Wiley, New York, 703 p.

Poulson, T. L. \& White, W. B. 1969. The cave environment. Science, 165: 971-981. http://dx.doi.org/10.1126/science.165.3897.971

Proudlove, G. S. 2010 - Biodiversity and distribution of the subterranean fishes of world. In: Trajano E., Bichuette M. E. \& Kapoor B. G. (Eds.), Biology of subterranean fishes. Science Publishers, Enfield. 41-63.

Holbrook R., Bomphrey R., Walker S., Taylor G., Thomas A. \& Burt de Perera T., 2007 - Swimming performance of a subcarangiform, the blind Mexican cave fish (Astyanax fasciatus). Comparative Biochemistry and Physiology - part A, 146: S119.

Romero A. \& McLeran A., 2000 - Threatened fishes of the world: Stygichthys typhlops (Brittan \& Böhlke, 1965) (Characidae).EnvironmentalBiologyofFishes, 57:270. http://dx.doi.org/10.1023/A:1007691926260

Romero A. \& Paulson K.M., 2001 - It's wonderful hypogean life: a guide to the troglomorphic fishes of the world. Environmental Biology of Fishes, 62: 1341. http://dx.doi.org/10.1023/A:1011844404235

Santos H.A., 2007 - A influência da capacidade natatória de peixes neotropicais no projeto hidráulico de mecanismos de transposição. Tese (Doutorado em Saneamento, Meio Ambiente e Recursos Hidricos), Universidade Federal de Minas Gerais, Belo Horizonte. 180 p.

Santos H.A., Pompeu P.S. \& Martinez C.B., 2007 - Swimming performance of the migratory Neotropical fish Leporinus reinhardti (Characiformes: Anostomidae). Neotropical Ichthyology, 5: 139-146. http://dx.doi.org/10.1590/S1679-62252007000200007
Santos H.A., Pompeu P.S., Vicentini G.S. \& Martinez C.B., 2008 - Swimming performance of the freshwater neotropical fish: Pimelodus maculatus Lacepède, 1803. Brazilian Journal of Biology, 68: 433-439. http://dx.doi.org/10.1590/S1519-69842008000200029

Statsoft, INC. 2009. Statistica for Windows (Computer program manual). Tulsa

Svendsen J.C., Tudorache C., Jordan A.D., Steffensen J.F., Aarestrup K. \& Domenici P., 2010 Partition of aerobic and anaerobic swimming costs related to gait transitions in a labriform swimmer. The Journal of Experimental Biology, 213: 2177218. http://dx.doi.org/10.1242/jeb.041368

Teyke, T. 1989 - Learning and remembering the environment in the blind cave fish. Journal of Comparative Physiology, A 164: 655-662. http://dx.doi.org/10.1007/BF00614508

Trajano E. \& Bichuette M. E., 2010 - Subterranean fishes of Brazil. In: Trajano E., Bichuette M. E. \& Kapoor B. G. (Eds.), Biology of subterranean fishes. Science Publishers, Enfield: 331-355.

Watson D.J. \& Balon E., 1984 - Ecomorphological analysis of taxocenes in rainforest streams of northern Borneo. Journal of Fish Biology, 25: 371-384. http://dx.doi.org/10.1111/j.1095-8649.1984.tb04885.x

Webb P.W., 1975 - Hydrodynamics and energetics of fish propulsion. Bulletin of the Fisheries Research Board of Canada, 190: 1-158

Weber A., Proudlove G. \& Nalbant T., 1996 - Morphology, systematic diversity, distribution, and ecology of stygobitic fishes. In: Weber A., Proudlove G., Parzefall J., Wilkens H. \& Nalbant T. (Eds.), Pisces (Teleostei). L'Encyclopaedia Biospeologica Tome II (Laboratoire Souterrain \& L'Institut de Speologie Emile Racovitza, 1996).

Wikramanayake E.D., 1990 - Ecomorphology and biogeography of a tropical stream fish assemblage: evolution of assemblage structure. Ecology, 71: 1756-1764. http://dx.doi.org/10.2307/1937583

Windsor S. P., Tan D. \& Montgomery J. C., 2008 Swimming kinematics and hydrodynamic imaging in the blind Mexican cave fish (Astyanax fasciatus). The Journal of Experimental Biology, 211: 29502959. http://dx.doi.org/10.1242/jeb.020453

Windsor S. P., Norris S. E., Cameron S. M., Mallinson G. D. \& Montgomery J. C., 2010a - The flow fields involved in hydrodynamic imaging by blind Mexican cave fish (Astyanax fasciatus). Part I: open water and heading towards a wall. The Journal of Experimental Biology, 213: 3819-3831. http://dx.doi.org/10.1242/jeb.040741

Windsor S. P., Norris S. E., Cameron S. M., Mallinson G. D. \& Montgomery J. C., 2010b - The flow fields involved in hydrodynamic imaging by blind Mexican cave fish (Astyanax fasciatus). Part II: gliding parallel to a wall. The Journal of Experimental Biology, 213: 3832-3842. http://dx.doi.org/10.1242/jeb.040790 